The Most Significant

Change technique

helps monitor

and evaluate

the performance

of projects and programs.

It involves the

collection and

systematic

participatory

interpretation of

stories of significant

change emanating from the field level-

stories about who did what, when, and why, and the reasons

why the event

was important.

It does not

employ quantitative

indicators.

\section{The Most Significant Change Technique}

\author{
by Olivier Serrat
}

\section{Rationale}

Development (as so much of knowledge and learning) is about change - change that takes place in a variety of domains. ${ }^{1}$ To move towards what is desirable and away from what is not, stakeholders must clarify what they are really trying to achieve, develop a better understanding of what is (and what is not) being achieved, and explore and share their various values and preferences about what they hold to be significant change. Evaluation has a role to play. However, on the word of Albert Einstein, "Not everything that can be counted counts, and not everything that counts can be counted."

\section{Definition}

The Most Significant Change technique is a qualitative and participatory form of monitoring and evaluation ${ }^{2}$ based on the collection and systematic selection of stories ${ }^{3}$ of reported changes from development activities. The technique was developed by Rick Davies in the mid-1990s to meet the challenges associated with monitoring and evaluating a complex participatory rural development program in Bangladesh, which had diversity in both implementation and outcomes. The technique is becoming popular, and adaptations have already been made.

\section{Benefits}

The Most Significant Change technique facilitates project and program improvement by focusing the direction of work away from less-valued directions toward more fully shared visions and explicitly valued directions, e.g., what do we really want to achieve and how

For instance, the domains might relate to changes in the quality of people's lives, the nature of their participation in development activities, or the sustainability of organizations.

Qualitative monitoring and evaluation is about learning: it is dynamic and inductive and therefore focuses on questioning. The data is hard to aggregate. Goal displacement is not an issue. Quantitative monitoring and evaluation is about proving (accountability): it is static and deductive and therefore focuses on measurement. The data is easy to aggregate. Goal displacement can be a problem. The Most Significant Change technique is a form of monitoring because it occurs throughout the project cycle and provides information to help people manage that. Michael Quinn Patton has argued that evaluation findings serve three primary purposes: to render judgments, to facilitate improvements, and/or to generate knowledge - the Most Significant Change technique contributes to evaluation because it provides data on outcomes that can be used to help assess the performance of a project or program as a whole.

Ideally, the stories will be 1-2 pages long in proforma. 
will we produce more of it? ${ }^{4}$ It can also help uncover important, valued outcomes not initially specified. It delivers these benefits by creating space for stakeholders to reflect, and by facilitating dynamic dialogue. As a corollary, project and program committees often become better at conceptualizing impact (and hence become better at planning). The unusual methodology of the Most Significant Change technique and its outcomes are a foil for other monitoring and evaluation techniques, such as logic models (results frameworks), appreciative inquiry, and outcome mapping - especially where projects and programs have diverse, complex outcomes with multiple stakeholders groups and financing agencies - to enrich summative evaluation with unexpected outcomes and very best success stories. What is more, the technique's reliance on participatory monitoring and evaluation can only enhance the chances that lessons will be learned and that recommendations will be acted upon. ${ }^{5}$

\section{Process}

The central process of the Most Significant Change technique is the collection and systematic selection of reported changes by means of purposive sampling with a bias in favor of success. This involves asking field staff to elicit anecdotes from stakeholders, focusing on what most significant change has occurred as the result of an initiative, and why they think that change occurred. These dozens, if not hundreds, of stories are passed up the chain and winnowed down to the most significant as determined by each management layer until only one story is selected - a story that describes a real experience, reviewed, defended, and selected by the people charged with the success of the project or program. Participants enjoy the process and usually bring to it a high level of enthusiasm - this owes mainly to the use of storytelling. ${ }^{6}$

\section{Enablers}

Six broad enabling contextual factors drive successful implementation of the Most Significant Change technique. These are

- Support from senior management.

- The commitment to the process of a leader.

- The development of trust between field staff and villagers.

- An organizational culture that prioritizes reflection and learning.

- Infrastructure that enables regular feedback of the results to stakeholders.

- Time to run several cycles of the technique.

\section{Caution}

The Most Significant Change technique is still evolving. Suggestions for improvements have been made, ${ }^{7}$ while others look to adapt it to different contexts or to combine it creatively with other approaches. Further, although it can address what follows, the Most Significant Change technique should not be used to

- Capture expected change.

- Prepare stories for public relations.

- Understand the average experience of stakeholders.

- Generate an evaluation report for accountability purposes.

- Conduct a quick evaluation.

- Conduct retrospective evaluation of a completed project or program.

$4 \quad$ The Most Significant Change technique differs from common monitoring and evaluation techniques in at least four respects: the focus is on the unexpected (rather than predetermined quantitative indicators that do not tell stakeholders what they do not know they need to know); information about change is documented in text, not numbers; major attention is given to explicit value judgments; and information is analyzed through a structured social process.

5 Some have suggested that the technique could the technique could be improved by adding a process to formally incorporate the lessons learned from the stories into short-term and long-term project or program planning. This might be accomplished by requesting those who report stories to make recommendations for action drawing from the stories they selected.

$6 \quad$ The advantage of stories is that people tell them naturally (indigenously). Stories can also deal with complexity and context and can carry hard messages (undiscussables) that people remember. However, they are not known for accuracy (truth).

7 Some have suggested that the technique could be revised to elicit and include the voices of critics and non-participants, conduct en masse participatory analysis of stories, improve the feedback process, and establish a formal process for incorporating the insights gained into both short- and long-term project and program planning. 
Box: Overview of Implementation Steps

\begin{tabular}{|c|c|}
\hline What? & Why? \\
\hline $\begin{array}{l}\text { 1. Getting started: establishing } \\
\text { champions and getting } \\
\text { familiar with the approach }\end{array}$ & $\begin{array}{l}\text { - The plan orientates itself to the needs of the users. It relies on appropriate form, language, and } \\
\text { information content levels. }\end{array}$ \\
\hline $\begin{array}{l}\text { 2. Establishing "domains } \\
\text { of change" }\end{array}$ & $\begin{array}{l}\text { The plan incorporates various dissemination methods, such as written, graphical, electronic, } \\
\text { and verbal media. The methods include research summary documents; press releases; media } \\
\text { coverage; flyers, posters, and brochures; letters of thanks to study participants; newsletters to } \\
\text { study participants; events and conferences; and seminars. Each method calls for its own format } \\
\text { and means of dissemination and includes both proactive and reactive channels - that is, it } \\
\text { includes information content that users have identified as important and information content } \\
\text { that users may not know to request but are likely to need. The dissemination methods are } \\
\text { more likely to succeed when their packaging and information content has been influenced by } \\
\text { appropriate inputs from the users. }\end{array}$ \\
\hline $\begin{array}{l}\text { 3. Defining the reporting } \\
\text { period }\end{array}$ & $\begin{array}{l}\text { - The plan draws on existing resources, relationships, and networks to the maximum extent } \\
\text { possible. It also builds the new resources, relationships, and networks needed by users. }\end{array}$ \\
\hline 4. Collecting stories of change & $\begin{array}{l}\text { - The plan includes effective quality control mechanisms to ensure that the information content } \\
\text { is accurate, relevant, and representative. }\end{array}$ \\
\hline $\begin{array}{l}\text { 5. Reviewing the stories } \\
\text { within the organizational } \\
\text { hierarchy }\end{array}$ & $\begin{array}{l}\text { - To make explicit what individuals and wider groups value as significant change } \\
\text { - To broaden understanding of what is seen as significant change in a project or program } \\
\text { as a whole } \\
\text { - To abstract and synthesize common elements of significant change } \\
\text { - To provide a source of evaluation information to stakeholders }\end{array}$ \\
\hline $\begin{array}{l}\text { 6. Providing stakeholders with } \\
\text { regular feedback about the } \\
\text { review process }\end{array}$ & $\begin{array}{l}\text { - To inform each subsequent round of story collection and selection } \\
\text { - To effectively record and adjust the direction of attention and the criteria used to value events } \\
\text { - To deepen organizational learning about the changes engendered by the project or program }\end{array}$ \\
\hline $\begin{array}{l}\text { 7. Setting in place a process } \\
\text { to verify the stories, } \\
\text { if necessary }\end{array}$ & $\begin{array}{l}\text { - To check that stories have been reported accurately and honestly } \\
\text { - To provide an opportunity to gather more detailed information about events seen } \\
\text { as especially significant }\end{array}$ \\
\hline 8. Quantification & $\begin{array}{l}\text { - To include quantitative information as well as qualitative information } \\
\text { - To quantify the extent to which the most significant changes identified in one location have } \\
\text { taken place in other locations within a specific period } \\
\text { - To monitor the monitoring system itself }\end{array}$ \\
\hline $\begin{array}{l}\text { 9. Conducting secondary } \\
\text { analysis of the stories } \\
\text { en masse }\end{array}$ & $\begin{array}{l}\text { - To identify main themes and differences among stories } \\
\text { - To theorize about change } \\
\text { - To encourage further publication via articles, conference papers, etc. }\end{array}$ \\
\hline $\begin{array}{l}\text { 10. Revising the Most } \\
\text { Significant Change process }\end{array}$ & $\begin{array}{l}\text { To revise the design of the Most Significant Change process to take into account what has been } \\
\text { learned as a direct result of using it and the findings, conclusions, and recommendations } \\
\text { from that }\end{array}$ \\
\hline
\end{tabular}

Source: Rick Davis and Jess Dart. 2005. 'The Most Significant Change' (MSC). Technique: A Guide to Its Use. Manila. Available: www.mande. co.uk/docs/MSCGuide.pdf

\section{Further Reading}

Rick Davies and Jess Dart. 2005. The 'Most Significant Change' (MSC) Technique: A Guide to Its Use. Manila. Available: www.mande.co.uk/docs/mscguide.pdf

ADB. 2008a. Appreciative Inquiry. Manila. Available: www.adb.org/documents/information/knowledgesolutions/appreciative-inquiry.pdf

2008b. Outcome Mapping. Manila. Available: www.adb.org/documents/information/knowledgesolutions/outcome-mapping.pdf

2008c. Output Accomplishment and the Design and Monitoring Framework. Manila. Available: www.adb.org/documents/information/knowledge-solutions/output-accomplishment.pdf 2008d. Storytelling. Manila. Available: www.adb.org/documents/information/knowledge-solutions/ storytelling.pdf 


\title{
Knowledge
Solutions
}

\author{
For further information \\ Contact Olivier Serrat, Head of the Knowledge Management Center, Regional and Sustainable Development Department, \\ Asian Development Bank (oserrat@adb.org).
}

Asian Development Bank

$A D B$, based in Manila, is dedicated to reducing poverty in the Asia and Pacific region through inclusive economic growth, environmentally sustainable growth, and regional integration. Established in 1966, it is owned by 67 members -48 from the region. In 2007, it approved $\$ 10.1$ billion of loans, $\$ 673$ million of grant projects, and technical assistance amounting to $\$ 243$ million.

.........................................................

Knowledge Solutions are handy, quick reference guides to tools, methods, and approaches that propel development forward and enhance its effects. They are offered as resources to ADB staff. They may also appeal to the development community and people having interest in knowledge and learning.

The views expressed in this publication are those of the author and do not necessarily reflect the views and policies of the Asian Development Bank (ADB) or its Board of Governors or the governments they represent. ADB encourages printing or copying information exclusively for personal and noncommercial use with proper acknowledgment of ADB. Users are restricted from reselling, redistributing, or creating derivative works for commercial purposes without the express, written consent of ADB.

\author{
Asian Development Bank \\ 6 ADB Avenue, Mandaluyong City \\ 1550 Metro Manila, Philippines \\ Tel +6326324444 \\ Fax +6326362444 \\ knowledge@adb.org \\ www.adb.org/knowledgesolutions
}

